\title{
文献情 報
}

付着生物研究会では, 付着生物に関連する論文および研究発表などを国内外より収集し, そのリストを読者に提供し ております。ここで取り上げた雑誌などは各担当者個人の入手可能な範囲とし，今回は1996 年 6 月より 1996 年 10 月 までの期間について行いました。対象とした雑誌などは以下に示すとおりですが, 関連するすのがなかった雑誌につい ては，特に記載しませんでした。

国内雑誌: 遺伝, うみうし通信, 海の研究, 海洋, 海洋と生物, 化学と工業, 化学と生物, 火力原子力発電, 環境科学 会誌, 官公庁公害専門資料, 現代化学, 産業之環境, 産業公害, 材料之環境, 色材協会誌, 水産の研究, 水産増殖, 蛋白・核酸・酵素, 電気化学および工業物理化学, 土木学会誌, 日本水産学会誌, 日本生態学会誌, 日本プランク トン学会誌，日本ベントス学会誌，ニュートン，PPM，防菌防徽，水環境学会誌，養殖，用水と廃水 口頭発表：海生生物污損対策愁談会, 電気化学協会, 日本水産学会

英文雑誌: Acta Zoologica (Stockholm), Austr. J. Mar. Freshw. Res., Biological Bulletin, Bulletin of Marine Science, Can. J. Fish. Aquatic Sci., Comp. Biochem. Physiol., Crustaceana, Ecological Research, EPRI J., Fisheries Science, J. Crustacean Biology, J. Mar. Biol. Ass. U.K., J. Marine Biotechnology, J. Experimental Marine Biology and Ecology, J. Oceanography, Marine Biology, Marine Chemistry, Marine and Freshwater Research, Marine Pollution Bulletin, Nature, Proceeding the Royal Society London B, Zoological Science

\section{国 内 雑 誌}

\section{遺伝}

1 干潟生態系 風呂田利夫 50(7), 19-23 (1996)

2 藻場生態系一アマモ場を中心に一 相生啓子 50(7), 24-29 (1996)

\section{化学と工業}

1 フラクタル構造を利用した超撥水材料 辻井 薰 49(7), 938-940 (1996)

2 海洋付着生物の棲み分け 志津芳一・磯合 敦・川原裕之 49(8), 1021-1024 (1996)

3 海洋付着生物の “着生フェロモン”廣田 洋 49(8), 1025-1026 (1996)

\section{電気化学および工業物理化学}

1 微生物の電気化学的殺菌とその応用 松永 是 $64(11), 1143$ (1996)

\section{口 頭 発 表}

平成 8 年度日本水産学会秋期大会 (1996 年 10 月, 九州大学)

1 マダイによる塩化トリブチルスズの経口濃縮特性に及ぼす飼料中濃度の影響 池田久美子・山田 久（中央水研）

2 韓国南部沿岸域における有機スズ污染と腹足類のインポセックス 堀口敏広 (国環研)・趙 (麗水水産大)・白石㝟 明・柴田康行・森田昌敏 (国環研) ・清水 誠 (東大)

3 ムラサキイガイを指標生物とした海域の重金属污染調査一大槌沙に生息するムラサキイガイの微量元素濃度一 山本義和・金崎聡子・伊藤昌子・宇野 綾（神戸女子学院大・人間科学）

4 含窒素化合物の相乗作用による付着阻害効果の向上 川又 睦・金子文夫 (大成建設) ・ 能勢泰祐・中川道也（積 水化学 $)$ ・川原裕之・志津里芳一 (海洋バイオ研)

5 タテジマフジッボ・キプリスの付着・变態のメカニズム 山本 久・㛢亚紀子・川井 悟・沖野龍文・吉村えり 奈・松村清隆・伏谷伸宏（新技団着生プロジェクト）

6 クダウミヒドラ幼生の定着・变態関与因子の探索 山下桂司・川井 悟・広田 洋・高橋美有紀・伏谷伸宏（新 技団着生プロジェクト) 
7 付着珪藻 Nitzchia laevis の增殖特性に関する研究 藤田睦一（関総環境セ）

8 走査型電子顕微鏡観察によるアマモ種子発芽時の外部形態について 福田富男（岡山水試）

9 褐藻アカモクとトゲモクの初期発育段階の光合成 水谷正貴・川口栄男・中園明信（九大農）

10 青森県深浦町沿岸における褐㩰フシスジモクの生長 藤川義一・桐原真二（青森増殖セ）・能登谷正浩（東水大）

11 波浪場における流れ藻の挙動と流体力特性について 瀬戸雅文 (道中央水試)・山田俊郎（西村組）・櫻井 泉（道 中央水試)

12 北海道西岸の磯焼け場とホソメコンブ群落中におけるコンブ遊走子量 太田雅隆・道津光生・野村浩貴（海生 研)・上田重貴・相内雄田大 (エコニクス)

13 ホソメコンブによるフルボ酸鉄摂取機構について 和 五郎・久万健志・松永勝彦（北大水）

14 フジッボノウプリウスの凍結保存 Khin Maungoo・岡本 研・黒倉 寿・日野明徳（東大水実）

15 付着物が付着した平面網地の抵抗係数について 山口恭弘（長大水）

16 ウミゥシ類のタテジマフジッボ着生阻害作用について 沖野龍文・吉村えり奈・廣田 洋・伏谷伸宏（新技団着 生プロジェクト)

17 有害渦鞭毛藻 Heterocapsa circularisquama がムラサキイガイの生残等に及ぼす影響 松山幸彦・内田卓志（南西水 研) - 本城凡夫（九大農）

\section{Biological Bulletin}

1 Transdifferentiation of larval flagellated cells to choanocytes in the metamorphosis of the demosponge Haliclona permollis. S. Amano and I. Hori 190(2), 161-172 (1996)

2 Expression sites of two byssal protein genes of Mytilus galloprovincialis. D. Miki, Y. Takeuchi, K. Inoue and S. Odo 190(2), 213-217 (1996)

3 Reversing the life cycle: medusae transforming into polyps and cell transdifferentiation in Turritopsis nutricula (Cnidaria, Hydrozoa). S. Piraino, F. Boero, Brigitte Aeschbach, V. Schmid 190, 302-312 (1996)

4 Chemical mediation of sperm activity and longevity in the solitary ascidians Ciona intestinalis and Ascidiella aspersa. T. Bolton and J. N. Havenhand 190, 329-335 (1996)

5 A chemical cue induces settlement of sydney rock oyster, Saccostrea commercialis, in the laboratory and in the field. M. J. Anderson 190, 350-358 (1996)

6 Cement proteins of the acorn barnacle, Megabalanus rosa. K. Kamino, S. Odo and T. Maruyama 190, 403-409 (1966)

7 DNA-synthesizing cells in the heart of Ascidia obliqua (Tunicata). M. G. Martynova and A. Nylund 190, 410-417 (1966)

Bull. Mar. Sci.

1 Spatial patterns in biodiversity of a fringing reef community along Ppunohu Bay, French Polynesia. M. Adjeroud and B. Salvat 59(1), 175-187, 1996.

2 Spatial distributions of the calcarious hydrozoans Millepora complanata and Millepora squarrosa on coral reefs. J. B. Lewis 59(1), 188-195, 1996.

3 Systematic relationships between tropical Corallimorpharians (Cnidaria, Anthozoa, Corallimorpharia)-Utility of the $5.8 \mathrm{~S}$ and internal transcribed spacer (ITS) regions of the rRNA transcription unit. C. A. Chen, B. L. Willis and D. J. Miller 59(1), 196-208, 1996.

4 Synchronous spawning of Acropora clathrata coral colonies from the western Arabian Gulf (Saudi Arabia). Y. H. Fadlallah 59(1), 209-216, 1996.

5 A new genus and species of Aulocalycidae, Leioplegma polyphyllon, (Porifera, Hexactinellida) from the Blake ridge off south Carolina, USA. H. M. Reiswig and M. Tsurumi 58(3), 764-774, 1996.

6 Relative habitat suitability and stability of the mediterranean gorgonian coral Eunicella cavolini (Coelenterata, Octocorallia). M. G. Weinbauer and B. Velimirov 58(3), 786-791, 1996.

7 Interspecific interactions and competitive ability of the polymorphic reef-building coral Montastrea anuularil. M. L. J. Vanveghel, D. F. R. Cleary and R. P. M. Bak 58(3), 792-803, 1996.

8 Recycling of ammonium within a hydrocoral (Millepora dichotoma)-zooxanthellae-cirripede (Savignium milleporum) symbiotic association. Y. Achituv and L. Mizrahi 58(3), 856-860, 1996.

9 Epizoic bryoozoans, horseshoe crabs, and other mobile benthic substrates (Review). M. M. Key, W. B. Jeffries, H. K. Voris and C. M. Yang 58(2), 368-384, 1996. 
10 Biomass patterns in seagrass meadows of the Laguna Madre, Texas. C. P. Onuf 58(2), 404-420, 1996.

11 New Primnoid gorgonians (Coelenterata, Octocorallia) from anterctic waters. F. M. Bayer 58(2), 511-530, 1996.

12 Distribution, abundance and species composition of juvenile scleractinian corals in the Florida reef tract. $M$. Chiappone and K. M. Sullivan 58(2), 555-569, 1996.

13 Cavity dwellers (Coelobites) under coral bubble in southernbelize barrier and atoll reefs. E. Gischler and R. N. Ginsburg 58(2), 570-589, 1996.

14 Pycnoclavellabelizeana, a new species of ascidian from the Carribean. I. Goodbody 58(2), 590-597, 1996.

15 Spicule dissolution in living Tethya omanensis (Porifera, Demospongiae) from a tropical cave. G. Bavestrello, R. Cattaneovietti, C. Cerrano and M. Sera 58(2), 598-601, 1996.

16 Rhodelinda gardineri (Gohar, 1940) (Coelenterata, Anthozoa) a stoloniferous octocoral from Patagonian shallow. G. Pastorino and C. Ituarte 58(1), 196-202, 1996.

17 Interaction of physical and biological factors in the large-scale distribution of juvenile queen conch in seagrass meadows. A. W. Stoner, P. A. Pitts and R. A. Armstrong 58(1), 217-233, 1996.

18 Reproductive and genetic variation among Carribean gorgonians-The differentiation $f$ Plexaura kuna, new species. H. R. Lasker, K. Kim and M. A. Coffroth 58(1), 277-288, 1996.

19 Wave-like outward growth of some tabele- and plate-forming corals, and a hypothetical mechanism. J. Stimpson 58(1), 301-313, 1996.

\section{Canadian Journal of Fisheries and Aquatic Sciences}

1 Nitrogen and phosphorus recycling by the zebra mussel (Dreissena polymorpha) in the western basin of Lake Erie. D. L. Arnott and M. J. Vanii 53(3), 646-659, 1996.

2 Identification of annually produced opaque bands in the shell of the freshwater mussel Elliptio complanata using the seasonal cycling of delta-O-18. G. I. Veinott and R. J. Cornett 53(2), 372-379, 1996.

3 Filtration dynamics of the zebra mussel, Dreissena polymorpha. J. Lei, B. S. Payne and S. Y. Wang 53(1), 29-37, 1996.

4 Biofilm and substrate preference in the Dreissenid larvae of Lake Erie. B. C. Wainman, S. S. Hincks, N. K. Kaushik and G. L. Mackie 53(1), 134-140, 1996.

5 Influence of biological factors on concentrations of metals in the tissue of freshwater mussel (Elliptio complanta and Lampsilis radiata radiata) from the St. Lawrence Rever. J. L. Metcalfesmith, R. H. Green and L. C. Grapentine 53 (1), 205-219, 1996.

6 Impact of zebra mussel (Dreissena polymorpha) on phosphorus cycling and chlorophyll in lakes. E. Mellina, J. B. Rasmussen and E. L. Mills 52(12), 2553-2573, 1995.

7 Elimination rate constants of 36 PC B s in zebra mussels (Dreissena polymorpha) and exposure dynamics in the lake St. Clair Lake Erie corridor. H. Morrison, T. Yankovich, R. Lazar and G. D. Haffner 52(12), 2574-2582, 1995.

8 Comparison of taxa of the mussel (Bivalvia) by analysis of the nuclear small-subunit rRNA gene sequence. E. Kenchington, D. Landry and C. J. Bird 52(12), 2613-2620, 1995.

9 PCR-based nuclear markers identify alien blue mussel (Mytilus spp.) genotypes on the west coast of Canada. D. D. Heath, P. D. Rawson and T. J. Hilbish 52(12), 2621-2627, 1995.

10 Lethal and sublethal effects of sponge overgrowth on introduced Dreissenid mussels in the Great Lakes St. Lawrence River system. A. Ricciardi, F. L. Snyder, D. O. Kelch and H. M. Reiswig 52(12), 2695-2703, 1995.

\section{Comparative Biochemistry and Physiology}

1 Proteolytic activity and vanadium inhibition in ascidian blood cells. S. Scippa et al. 114(4), 291-296, 1996.

2 The biochemical transformation of food by the mussel Mytilus galloprovinciallis Lamarck at different temperatures. A. V. Frolov and S. L. Pankov 112(3-4), 441-453, 1996.

\section{Crustaceana}

1 Dessication tolerance of the barnacle Semibalanus balanoides (1) in relation to shore height (Cirripedia, Thoracica). F. J. Ware and R. G. Hartnoll 69, 321-329, 1996.

2 First records of the pelagic larvae of Peltogaster paguri Rathke, 1842 (Cirripedia, Rhizocephala, Peltogastridae) in Arctic waters. S. F. Timofeev 69, 114-116, 1996.

\section{Journal of Experimental Marine Biology and Ecology}

1 Induction of metamorphosis in queen conch, Strombus gigas Linnaeus, larvae by cues associated with red algae from their nursery grounds. A. A. Boettcher, N. M. Targett 196, 29-52 (1996) 
2 Bioactivity of echinoderm ethanolic body-wall extracts: an assessment of marine bacterial attachment and macroinvertebrate larval settlement. P. J. Bryan, D. Rittschof, J. B. McClintock 196, 79-98 (1996)

3 Colonisation and decelopment in encrusting communities from the Antarctic intertidal and sublittoral. D. K. A. Barnes, P. Rothey, A. Clarke 196, 251-265 (1996)

4 Competition in encrusting Antarctic bryozoan assemblages: outcomes, influences and implications. D. K. A. Barnes, P. Rothey 196, 267-284 (1996)

5 Macrogeographic differentiation by mtDNA restriction site analysis in the S.W. European Mytilus galloprovincialis Lmk. A. Sanjuan, A. S. Comesena, A. De Carlos 198, 89-100 (1996)

6 The effect of starvation on acquisition of competence and post-metamorphic performance in the marine prosobranch gastropod Crepidula fornicata (L.). J. A. Pechenik, K. Hammer, C. Weise 199(1), 137-152 (1996)

7 Barnacle population dynamics and recritment regulation in southcentral Alaska. M. L. Carroll 199(2), 285-302 (1996)

8 Biotic interactions in the colonization of crustose coralline algae by epiphytes. M. A. O. Figueiredo, J. M. Kain, T. A. Norton 199(2), 303-318 (1996)

9 Ontogenetic trends of elements ( $\mathrm{Na}$ to $\mathrm{Sr}$ ) in prismatic shell of living Crassostrea virginica (Gmelin) grown in three ecologically dissimilar habitats for 28 weeks: a proton probe study. M. R. Carriker, C. P. Swann, J. Ewart, C. L. Counts III 201(1-2), 87-136 (1996)

10 Scale of observation and distribution of adult conspecifics: their influence in assessing passive and active settlement mechanisms in the barnacle Balanus crenatus (Brugiere). G. Miron, E. Bourget, P. Archambault 201(1-2), 137-158 (1996)

11 Chemical defenses of the tropical green seaweed Neomeris annulata Dickie: effects of multiple compounds on feeding by herbivores. W. A. Lumbang, V. J. Paul 201(1-2), 185-196 (1996)

12 Algal zonation in tidepools: experimental evaluation of the roles of physical disturbance, herbivory and competition. P. G. van Tamelen 201(1-2), 197-232 (1996)

13 Sex pheromones in marine polychaetes V: a biologically active volatile compound from the coelomic fluid of female Nereis (Neanthes) japonica (Annelida Polychaeta). H. D. Bartels-Hardege, J. D. Hardege, E. Zeeck, C. Muller, B. L. Wu, M. Y. Zhu 201(1-2), 275-284 (1996)

\section{Marine Biology}

1 The encrusting sponge Halisarca laxus-population genetics and association with the ascidian Pyura spinifera. A. R. Davis et al. 126(1), 27-33, 1996.

2 Association among ascidians-facilitation of recruitment in Pyura spinifera. A. R. Davis 126(1), 35-41, 1996.

3 Permeability of the oral epithelial layers in Cnidarians. S. Benazettambutte et al. 126(1), 43-53, 1996.

4 Interspecific variation in thermal denaturation of proteins in the congeneric mussels Mytilus trossulus and $M$. galloprovincialis-evidence from the heat shork response and protein ubiquitination. G. E. Hofmann and G. N. Somero 126(1), 65-75, 1996.

5 Annual cycle of expression of connective tissue polypeptide markers in the mantle of the mussel Mytilus galloprovincialis. A. T. Mikhailov et al. 126(1), 77-89, 1996.

6 Effects of ultraviolet and photosynthetically active radiation of five seagrass species. S. P. Dawson and W. C. Dennison 125(4), 629-638, 1996.

7 Photoinhibition and recovery of the kelp Laminaria saccharina at optimal and superoptimal temperatures. J. Bruhn and V. A. Gerard 125(4), 639-648, 1996.

8 Symbiotic zooxanthellae enhance boring and growth rates of the tropical sponge Anthosigmella varians forma varians. M. S. Hill 125(4), 649-654, 1996.

9 Ultrastructure of the spirocyst tubule in black corals (Coelenterata, Antipatharia) and its taxonomic implications. W. M. Goldberg and G. T. Taylor 125(4), 655-662, 1996.

10 Autoradiographic investigation of uptake and storage of exogenous sperm by the ovary of the compound ascidian Diplosoma listerrianum. J. D. D. Bishop and A. D. Sommerfeldt 125(4), 663-670, 1996.

11 Assimilation of trace elements by the mussel Mytilus edulis-Effects of diatom chemical composition. W. X. Wang and N. S. Fisher 125(4), 715-724, 1996.

12 Influence of body size on the uptake, depuration, and dioaccumulation of polycholorinated biphenyl congeners by Baltic sea blue mussel, Mytilus edulis. M. Gilek, N. Bjork and C. Naf 125(3), 499-510, 1996.

13 Reef coral reproduction in the eastern Pacific-Costa Rica, Panama, and Galapagos Islands (Ecuador). 3. Arariciidae (Pavona gigantea and Gardineroseris planulata). P. W. Glynn et al. 125(3), 579-601, 1996. 
14 Quantification of sexual reproduction in the marine benthic hydroid cCampanularia everta. R. Coma et al. 125(2), 365-373, 1996.

15 The Mytilus edulis species complex in southwest England-effects of hybridization and introgression interlocus associations and morphometric variation. J. P. A. Gardner 125(2), 385-399, 1966.

16 Antimicrobial activity of extracts of Caribbean gorgonian corals. P. R. Jensen et al. 125(2), 411-419, 1996.

17 Genetic subdivision in the subtidal, clonal sea anemone Anthothoe albocincta. M. Billingham and D. J. Ayre 125(1), 153-163, 1996.

18 The multixenobiotic resistance mechanism in the marine sponge Suberites domuncula-its potensial applicability for the evaluation of environmental pollution by toxic compounds. W. E. G. Muller et al. 125(1), 165-170, 1996.

19 Copper effects on reproductive stages of baltic sea Fucus vesiculosus. S. Anderson and L. Kautsky 125(1), 171-176, 1996.

20 Distribution of algae on tropical rocky shores - spatial and temporal patterns of non-coralline encrusting algae in Hongkong. S. Kaehler and G. A. Williams 125(1), 177-187, 1996.

21 Seasonal reproduction in deep sea sponges-triggered by vertical particle flux. U. Witte 124(4), 571-581, 1996.

22 Location of toxicity within the mediterranean sponge Crambe crambe (Demospongiae, Poecilosclerida). M. J. Uriz et al. 124(4), 583-590, 1996.

23 Genetic variation among populations of Mytilus spp. in eastern Newfoundland. J. A. Bates and D. J. Innes 124(3), 417-424, 1996.

24 Life history characteristics of a coral reef sponge. E. Meroz and M. Ilan 124(3), 443-451, 1996.

25 Cohabitation of a coral reef sponge and a colonial scyphozoan. E. Meroz and M. Ilan 124(3), 453-459, 1996.

26 Phototaxis in Fungiidae corals (Scleractinia). H. Yamashiro and M. Nishihara 124(3), 461-465, 1996.

27 Distribution of male and female mtDNA linages in populations of blue mussels, Mytilus trossulus and M. galloprovincialis, along the Pacific coast of North America. P. D. Rawson and T. J. Hilbish 124(2), 245-250, 1996.

28 Effects of chemical contaminations on the health of Mytilus edulis from Puget Sound, Washington. 2. Cytochemical detection of subcellular changes in digestive cells. P. K. Krishnakumar et al. 124(2), 251-259, 1996.

29 Highly repetitive DNA sequences provide evidence for a lack of gene flow between two morphological forms of Herdmania momus (Ascidiacea, Stolidobranchia). B. M. Degnan et al. 124(2), 293-299, 1996.

30 Extensive gene flow among mytilid (Bathymodiolus thermophilus) populations from hydrothermal vents of the eastern Pacific. C. Craddock et al. 124(1), 137-146, 1996.

\section{Journal of the Marine Biological Association of the United Kingdom}

1 Vertical changes in density, size structure and shell shape of the bivalve Lassea undulata within intertidal mussel beds. K. Iwasaki 76(2), 417-430, 1996.

2 Patterns of biodiversity in the macro-invertebrate fauna associated with mussel patches on rocky shores. R. Seed 76(1), 203-210, 1996.

3 The influence of the introduced tropical alga Caulerpa taxifolia, on the biodiversity of the mediterranean marine biota. D. Bellansantini et al. 76(1), 235-237, 1996.

4 Hidden diversity in marine algae - Some examples of genetic variation below the species. M. J. H. Vanoppen et al. 76 (1), 239-242, 1996.

5 Iron biomineralization in the poriferan Ircinia oros. F. C. Meldrum et al. 75(4), 993-996, 1995.

\section{Journal of Marine Biotechnology}

1 Biofouling and marine biotechnology: New antifoulants from marine invertebrates. W. Miki, K. Kon-ya, S. Mizobuchi 4, 117-120 (1996)

2 A newly developed bioassay system for antifouling substances using the blue mussel, Mytilus edulis galloprovincialis. Y. Hayashi, W. Miki 4, 127-130 (1996)

\section{Marine Ecology-Progress Series}

1 A multi-scale analysis of settlement density and pattern dynamics of the barnacle Semibalanus balanoides. J. M. Hills, J. C. Thomason 138(1-3), 103-115, 1996

2 Role of catastrophic disturbance in mediating Nucella-Mytilus interactions in the Alaskan Rocky intertidal. M. L. Carroll, R. C. Highsmith 138(1-3), 125-133, 1996

3 Physiological energetics of the horse mussel Modiolus modiolus in a cold ocean environment. J. M. Navarro, R. J. Thompson 138(1-3), 135-148, 1996. 
4 Effects of physical factors on larval behavior, settlement and recruitment of four tropical demosponges. M. Maldonado, C. M. Young 138(1-3), 169-180, 1996

5 Genetic evidence for extensive cryptic speciation in the subtidal sponge Plakina trilopha (Porifera, Demospongiae, Homoscleromorpha) from the western Mediterranean. G. Muricy et al. 138(1-3), 181-187, 1996

6 Patterns of reproductive effort in the brown alga Ascophyllum nodosum. P. Aberg 138(1-3), 199-207, 1996

7 Interactive effects of inducible defense and resource availability on phlorotannins in the north Atlantic brown alga Fucus vesiculosus. P. Peckol et al. 138(1-3), 209-217, 1996

8 Nutrient limitation of Philippine seagrasses (Cape Balinao, NW Philippines) -in situ experimental evidence. N. S. R. Agawin et al. 138(1-3), 233-243, 1996

9 Wind driven settlement patterns in the acorn barnacle Semibalanus balanoides. M. D. Bartness et al. 137(1-3), 103$110,1996$.

10 Bioavailability of dissolved zinc to the common mussel Mytilus edulis in complexing environments. $\mathbf{K}$. Vercauteren, $\mathbf{R}$. Blust 137(1-3), 123-132, 1996

11 Settlement and early post settlement survival of sessile marine invertebrates on topographically complex surfaces-the importance of refuge dimensions and adult morphology. L. J. Walters, D. S. Wethey 137(1-3), 161-171, 1996

12 Sulphate reduction in the root zone of the seagrass Zostera noltii on the intertidal flats of a coastal lagoon (Arcachon, France). M. F. Isaksen, K. Finster 137(1-3), 187-194, 1996

13 Non-structural carbohydrate reserves of eelgrass Zostera marina. M. K. Burke et al. 137(1-3), 195-201, 1996

14 Growth and population dynamics of Posisonia oceanica on the spanish mediterranean coast-elucidating seagrass decline. N. Marba et al. 137(1-3), 203-213, 1996

15 Photosynthesis and inorganic carbon utilization in Pleurochrysis sp. (Haptophyta), a coccolithophorid alga. A. A. Israel, E. L. Gonzalez 137(1-3), 243-250, 1996

16 Modeling the vertical distribution of oyster larvae in response to environmental conditions. M. M. Dekshenieks et al. 136(1-3), 97-110, 1996

17 Resorce competition between macrobenthic epifauna and infauna in a Kenyan Avicennia marina mangrove forest. J. Schrijvers et al. 136(1-3), 123-135, 1996

18 Cloning of a heat inducible biomaker, the cDNA encoding the $70 \mathrm{KDa}$ heat shock protein, from the marine sponge Geodia cydonium-response to natural stressors. C. Koziol et al. 136(1-3), 153-161, 1996

19 Dynamics of solar bleaching in the intertidal reef coral Goniastrea aspera at Ko Phuket, Thailand. M. D. A. Letissier, B. E. Brown 136(1-3), 235-244, 1996

20 Consequences of morphology and tissue strength to blade survivorship of two closely related rhodophyta species. F. J. Shaughnessy et al. 136(1-3), 257-266, 1996

21 Predicting population decline-seagrass demographixs and the reconstructive technique. S. L. Jensen et al. 136(1-3), 267-276, 1996

22 Effects of light/dark transition on carbon translocation in eelgrass Zostera marina seedlings. R. C. Zimmerman, R. S. Alberte 136(1-3), 305-309, 1996

23 Early post-settlement mortality of an intertidal barnacle - a critical period for survival. L. A. Gosselin, P. Y. Qian 135 (1-3), 69-75, 1996.

24 Substratum heterogeniety and complexity influence micro-habitat selection of Balanus sp. and Tubularia crocea larvae. M. Lemire, E. Bourget 135(1-3), 77-87, 1996

25 Shell remains provide clues to historical distribution and abundance patterns in a large seagrass-associated gastropod (Strombus gigas). A. W. Stone, M. Ray 135(1-3), 101-108, 1996

26 Multiple-locus heterozygosity, physiolog and growth at two different stages in the life cycle of the Chilean oyster Ostrea chilensis. J. E. Toro et al. 134(1-3), 151-158, 1996

27 Action spectrum for the effects of UV radiation on photosynthesis in the hermatypic coral Pocillophora damicornis. M. P. Lesser, S. Lewis 134(1-3), 171-177, 1996

28 Regeneration versus budding in fungiid corals - a trade-off. E. Kramarskywiner, Y. Loya 134(1-3), 179-185, 1996

29 Regulation of lighe attenuation and eelgrass Zostera marina depth distribution in a Danish embayment. B. Olsen 134 (1-3), 187-194, 1996

30 Nutrient uptake by leaves and roots of the seagrass Thalassia hemprichii in the Spermonde Archipelago, Indonesia. J. Staple et al. 134(1-3), 195-206, 1996

31 Modelling coral reef biodiversity and habitat destruction. Stone L et al. 134(1-3), 299-302, 1996

32 Tridimensional matrices of mussels Perumytilus purpuratus on intertidal platoforms with varying wave forces in central Chile. J. L. Albarado, J. C. Castilla 133(1-3), 135-141, 1996. 
33 Comparative study on the contamination and decontamination of Japanese oyster Crassostrea gigas and bule mussel Mytilus edulis by oxytetracycline and oxolinic acid. H. Pouliquen et al. 133(1-3), 143-148, 1996

34 Responses of compound ascidian larvae to haloclines. E. Vazquez, C. M. Young 133(1-3), 179-190, 1996

35 Are neighbours harmful or helpful in Fucus vesiculosus populations. J. C. Creed et al. 133(1-3), 191-201, 1996

36 Growth patterns of western mediterranean seagrasses - species-specific responses to seasonal forcing. N. Marba et al. 133(1-3), 203-215, 1996

37 In situ submarine pollination in the seagrass Amphibolis antarctica-Research notes. J. J. Verduin et al. 133(1-3), 307-309, 1996

38 Development of planted seagrass beds in Tampa Bay, Florida, USA. 1. Plant components. M. S. Fonseca 132(1-3), 127-139, 1996

39 Importance of timing of panel exposure on the competitive outcome and succession of sessile organisms. M. S. Fonseca et al. 131(1-3), 191-203, 1996

40 Assessment of carbon allocation and biomass production in a natural stand of the salt marsh plant Spartina anglica using C-13. M. A. Hemminga 130(1-3), 169-178, 1996

41 Assimilation of trace elements ingested by the mussel Mytilus edulis-effects of algal food abundance. W. X. Wang et al. 129(1-3), 165-176, 1995

42 Fluxes of haemolymph ammonia and free amino acids in Mytilus edulis exposed to ammonia. S. Sadok et al. 129(13), 177-187, 1995

43 Contaminant-induced lysosomal membrane damage in blood cells of mussels Mytilus galloprovincialis from the Venice lagoon - an in vitro study. D. M. Lowe et al. 129(1-3), 189-196, 1995

44 Population dynamics of Mytilus edulis along environmental gradients-density-dependent changes in adult mussel numbers. S. Mcgrorty, J. D. Gsscustard 129(1-3), 197-213, 1995

45 Growth and energetics of the sponge Halichondria panicea. S. Thomassen, H. U. Riisgard 128(1-3), 239-246, 1995

46 Effects of cyclone joy on nearshore coral communities of the Great Barrier Reef. R. Vanwoesik et al. 128(1-3), 261 $-270,1995$

47 Scope for growth and contaminant levels in North Sea mussels Mytilus edulis. J. Widdows et al. 127(1-3), 131-148, 1995

48 Defenses of carribean sponges against predatory reef fish. 1. Chemical deterrency. J. R. Pawlik et al. 127(1-3), 183194,1995

49 Defenses of carribean sponges against predatory reef fish. 2. Spicules, tissue toughness, and nutritional quality. B. Chanas, J. R. Pawlik 127(1-3), 195-21, 1995

50 Effects of prolonged shading stress on growth and survival of seagrass Posidonia australis in Jervis Bay, New South Wales, Australia. J. Fitzpatrick, H. Kirkman 127(1-3), 279-289, 1995

\section{Marine and Freshwater Research}

1 Monitoring larval fluxes through the surf zones of australian coral reefs. P. Doherty and J. Mcilwain 47(2), 383-390, 1996.

2 Habitat selection before settlement by Pomacentrus coelestis. P. Doherty, et al. 47(2), 391-399, 1996.

3 Coral communities of the Gneering Shoals and Mudhimba Island, south-eastern Queensland. S. A. Banks and V. J. Harriott 46(8), 1137-1144, 1995.

4 Elevated sea-water temperature and solar UV-B flux associated with two successive coral mass bleaching events in Tahiti. J. H. Drollet et al. 46(8), 1153-1157, 1995.

5 Preliminary study of the distribution and photophysiology of the temerate phototrophic sponge Cymbastela sp. from south Australia. A. C. Cheshire et al. 46(8), 1211-1216, 1995.

\section{Marine Science}

1 A new genus and species of aulocalycidae, Leioplegma polyphyllon, (porifera: hexactinellioda) from the blake ridge off south carolina, USA. H. M. Reiswig and M. Tsurumi 58(3), 764-774 (1996)

\section{Proc. of the Royal Society of London, Series B: Biological Sciences}

1 Female control of paternity in the internally fertilizing compound ascidian Diplosoma listerianum. 2. Investigation of male mating success using rapd makers. J. D. D. Bishop et al. 263(1368), 249-256, 1996.

2 Female control of paternity in the internally fertilizing compound ascidian Diplosoma listerianum. 1. Autoradiographic investigation of sperm movements in the female reproductive tract. J. D. D. Bishop 263(1368), 369-376, 1996. 
3 Dynamics and growth patterns of calcareous sponge spicules. M. Ilan et al. 263(1367), 133-139, 1996.

4 Life history plasticity in chimaeras of the colonial ascidian Botryllus chlosseri. N. E. Chadwickfurman and I. L. Weissman, 262(1364), 157-162, 1995.

\section{Zoological Science}

1 Characterization of novel metallo-proteases released from ascidian hemocytes by treatment with calcium ionophore. K. Azumi, H. Yokosawa 13(3), 365-370 (1996)

2 Characterization of sea urchin sperm membrane proteins which interact with a major acrosome reaction-inducing substance, fucose sulfate glycoconjugate. Y. Satoh, T. Shimizu, T. Harumi, N. Suzuki 13(3), $377-384$ (1996)

3 The mechanism of accumulation of vanadium by ascidians: Some progress towards an understanding of this unusual phenomenon. H. Michibata 13(4), 489-502 (1996)

4 Fine structures of tunic cells and distribution of bacteria in the tunic of the luminescent ascidian Clavelina miniata (Ascidiacea, Urochordata). E. Hirose, M. Aoki, K. Chiba 13(4), 519-524 (1996)

5 Spatio-temporal expression patterns of eight epidermis-specific genes in the ascidian embryo. K. Ishida, T. Ueki, N. Satoh 13(5), 699-710 (1996)

6 Dephosphorylation of autophosphorylated regulatory subunit of sea urchin sperm cAMP-dependent histone kinase by an endogenous protein phosphatase. K. Hoshino, N. Suzuki 13(5), 711-718 (1996)

7 Two distinct cell types identified in the ascidian notochord. K. J. Tanaka, S. Chiba, T. Nishikatu 13(5), 725-730 (1996)

8 Phylogenetic relationships among turbellarian orders interred from 18 Sr DNA sequences. T. Katayama, M. Nishioka, M. Yamamoto 13(5), 747-756 (1996) 